\title{
QUANTITATIVE DETERMINATION OF POTASSIUM HYDROGENPEROXOMONOSULFATE IN "ECOCID S" DISINFECTANT BY CATHODIC VOLTAMMETRY
}

\author{
M.Ye.Blazheyevskiy, O.O.Mozgova \\ National University of Pharmacy \\ Key words: potassium hydrogenperoxomonosulfate; voltammetry; carbositall electrode; SDBS; \\ disinfectant
}

\begin{abstract}
The electrochemical behaviour of potassium hydrogenperoxomonosulfate $\left(\mathrm{KHSO}_{5}\right)$ in the presence of sodium dodecylbenzenesulfonate (SDBS) has been studied using cathodic voltammetry at the carbositall electrode as indicating in the potential range of $+1.0 \ldots-1.2 \mathrm{~V}$ (the reference electrode $\mathrm{Ag}$, $\mathrm{AgCl} / \mathrm{KCl}(\mathrm{sat}))\left(E_{p}=+0.3 \mathrm{~V}\right)$. It has been experimentally proven that the height of $\mathrm{KHSO}_{5}$ reduction peak decreases and the potential of the reduction peak is shifted toward more electronegative values with increasing of the background electrolyte $\mathrm{pH}$ from 0.80 to 7.17 . The maximum peak $\left(I_{p}\right)$ occurs at a $\mathrm{pH}$ of approximately 0.8 and at a $\mathrm{pH}$ around 5 the analytical signal almost disappears. The effect of $\mathrm{pH}$ on the peak potential $\left(E_{p}\right)$ shows the following: when the $\mathrm{pH}$ value increases in the interval from 0.8 to $2, E_{p}$ remains almost constant, but $E_{p}$ decreases sharply to the negative value with $p H$ increasing over 2. It has been experimentally proven that SDBS leads to increase of the current peak and the peak potential shifts to the more electropositive side $(+0.25 \rightarrow+0.3 \mathrm{~V})$. The influence of the present SDBS has been examined. The current peak increases with the concentration of the surfactant up to $1.2 \times 10^{-3} \mathrm{~mol} \mathrm{~L}^{-1}$ and then stays almost constant with the increase in the concentration of SDBS above $3.0 \times 10^{-3} \mathrm{~mol} \mathrm{L^{-1 }}$. The linear relationship was observed in the $\mathrm{KHSO}_{5}$ concentration range of $(1.8-9.0) \times 10^{-5} \mathrm{~mol} \mathrm{~L} L^{-1}$, the calibration curve equation was $I_{p}=(4.3 \pm 1.1) \times 10^{4} \mathrm{c}(r=0.998)$. When determining $\mathrm{KHSO}_{5}$ in the test solution of "Ecocid S" disinfectant with the concentrations of $4.65 \times 10^{-5}$, $6.20 \times 10^{-5}$ and $\left.7.75 \times 10^{-5} \mathrm{~mol} L^{-1}\right)$ the $R S D$ s were $0.025,0.023$ and 0.021 , respectively $(\delta=-0.64 \ldots$ $+0.16 \%) ; L O D=6.50 \times 10^{-6} \mathrm{~mol}^{-1}, L O Q=2.17 \times 10^{-5} \mathrm{~mol} \mathrm{~L}^{-1}$.
\end{abstract}

Potassium hydrogenperoxomonosulfate $\left(\mathrm{KHSO}_{5}\right)$ is one of the most widely used disinfectants in medical practice, among well-known classes of chemical disinfectants - oxidants. It is included in the new generation of modern disinfection agents in the form of a stable triple potassium salt $2 \mathrm{KHSO}_{5} \cdot \mathrm{KHSO}_{4} \cdot \mathrm{K}_{2} \mathrm{SO}_{4}$, such as "Perform" and modified analogue of "Virkon" - "Ecocid S" (KRKA, Slovenia, Novo mesto).

"Ecocid S" is a complex disinfectant in the form of a granulated water-soluble powder, which contains $\mathrm{KHSO}_{5}(50 \%)$ and such excipients as a surfactant sodium dodecylbenzenesulfonate (SDBS to $15 \%$ ), organic acids (malic and sulfamic acids), inorganic buffer systems (sodium polyphosphate, sodium chloride), an indicator of activity - azo dye and flavour with a citron odour. It is characterized by the broad-spectrum antimicrobial activity to bacteria, viruses, fungi, as well as to Mycobacterium tuberculosis [2, 4, 7-9]. It does not have the sensitizing and local irritative effect to the skin and is slightly irritating to the mucous membranes in regulated concentrations $(0.5-4 \%$ by the active substance). Working solutions remain active for 7 days. It does not have the corrosive action and the negative impact on the surface treated. It is applied for preventive and forced disinfection. SDBD acts as a surfactant, thus providing a contact with the pathogen oxidant; reacts with membrane lipids and proteins causing denaturation of the cell membranes.
Determination (mass fraction) of active oxygen (in terms of active chlorine) in the product is carried out by iodometric titration [15].

Scientific literature describes quantitative determination of $\mathrm{KHSO}_{5}$ in "Virkon" disinfectant by the method of pH-potentiometric titration with the standard solution of tin (II) chloride in the presence of potassium bromide using a point platinum and glass electrode [5].

Extensive literature survey reveals that various electrochemical methods have been reported for determination of electrochemically active compounds of various classes, including hydrogen peroxide and inorganic peroxides analysis $[11,13,14,20,21]$. Among them the method of voltammetry with the linear potential scan using a drop mercury electrode or its other modifications and solid platinum or gold electrodes is most commonly used. These electrodes are characterized by satisfactory reproducibility of research results and simple methods for their preparation. However, mercury is a toxic substance and other metals are rather expensive. It is also known that oxygen chemosorbs on $\mathrm{Au}$, as well as on Pt, and forms oxide films. Adsorbed oxygen is involved in the anodic process, and Au oxides inhibit processes of the analyte electrooxidation. Thus, the electrodes based on cheap carbon materials such as carbon glass, carbon paste, carbositall are widely used $[6,12$, 19]. They are characterized by high overpotential (low adsorption capacity in relation to $\mathrm{O}_{2}$ and $\mathrm{H}_{2}$ in the poten- 
tial work area) of hydrogen and/or oxygen (the ability to track multiple regeneration to obtain reproducible surface). In addition, these electrodes offer the ability to perform such analytical determinations, which mercury or other electrodes are not always possible to do. It has been very popular because of its excellent electrical and mechanical properties, a wide potential range, extreme chemical inertness and relatively reproducible performance $[10,16,17]$.

It has been previously proven that SDBS leads to increase of the $\mathrm{KHSO}_{5}$ reduction peak at the carbositall electrode and the addition method was used for $\mathrm{KHSO}_{5}$ determination in "Ecocid S" disinfectant, which contains SDBS surfactant [3].

In the present work the results of elaboration of the quantitative determination method for $\mathrm{KHSO}_{5}$ in the presence of SDBS by cathodic voltammetry at the carbositall electrode using the method of the calibration graph are presented.

\section{Experimental Part}

The solution of $\mathrm{KHSO}_{5}$ ("Oxone ${ }^{\mathbb{R} ",}$, ACROS ORGANICS) was freshly prepared and standardized iodometrically. The stock solution was prepared by dissolving $0.1537 \mathrm{~g}$ of the powder (triple potassium salt, $2 \mathrm{KHSO}_{5} \cdot \mathrm{KHSO}_{4} \cdot \mathrm{K}_{2} \mathrm{SO}_{4}$ ) in a $50 \mathrm{~mL}$ volumetric flask by double distilled water to give the concentration of $9 \times 10^{-2} \mathrm{~mol} \mathrm{~L}^{-1} .10 \mathrm{~mL}$ of $9 \times 10^{-2} \mathrm{~mol} \mathrm{~L}^{-1}$ solution of $\mathrm{KHSO}_{5}$ was diluted in a $100 \mathrm{~mL}$ volumetric flask with double distilled water to obtain $9 \times 10^{-3} \mathrm{~mol} \mathrm{~L}^{-1}$ of $\mathrm{KHSO}_{5}$ solution.

The solution of SDBS was prepared by dissolving $6.96 \mathrm{~g}$ of the powder in a $100 \mathrm{~mL}$ volumetric flask by double distilled water to give the concentration of $0.2 \mathrm{~mol} \mathrm{~L}^{-1}$.

The background solution was prepared by dissolving $68.1 \mathrm{~g}$ of potassium hydrogensulfate $\left(\mathrm{KHSO}_{4}\right)$ in a $500 \mathrm{~mL}$ volumetric flask by double distilled water to give the concentration of $1 \mathrm{~mol} \mathrm{~L}^{-1}$.

The $\mathrm{pH}$ was measured using an ionmeter of I-160M type (Belarus) with a glass electrode of ESL-43-07 type paired with $\mathrm{Ag}, \mathrm{AgCl} / \mathrm{KCl}$ (sat) electrode.

Electrochemical measurements were carried out in an AVS-1.1 analyzer (Volta, St. Petersburg) with a threeelectrode scheme by alternating the current mode with a square wave modulation in the potential range of $+1.0 \ldots-1.2 \mathrm{~V}, \mathrm{~W}=1000 \mathrm{rpm}$, the amplitude of $40 \mathrm{mV}$, $v=65 \mathrm{~Hz}$. The values of potential peaks directly at the maximum were measured by the electrochemical sensor "Module EM-04" with the accuracy of $\pm 5 \mathrm{mV}$. The carbositall electrode was used as a working and an auxiliary electrode, and $\mathrm{Ag}, \mathrm{AgCl} / \mathrm{KCl}$ (sat) electrode type EVL-1M4 as a reference electrode.

The scheme of the reduction process is as follows:

$$
\mathrm{HSO}_{5}^{-}+2 \bar{e}+2 \mathrm{H}^{+} \rightarrow \mathrm{HSO}_{4}^{-}+\mathrm{H}_{2} \mathrm{O}
$$

\section{Results and Discussion}

The effect of the nature and $p H$ of the background solution

It has been experimentally proven that the height of $\mathrm{KHSO}_{5}$ reduction peak at the carbositall electrode surface decreases, and the potential of the reduction peak

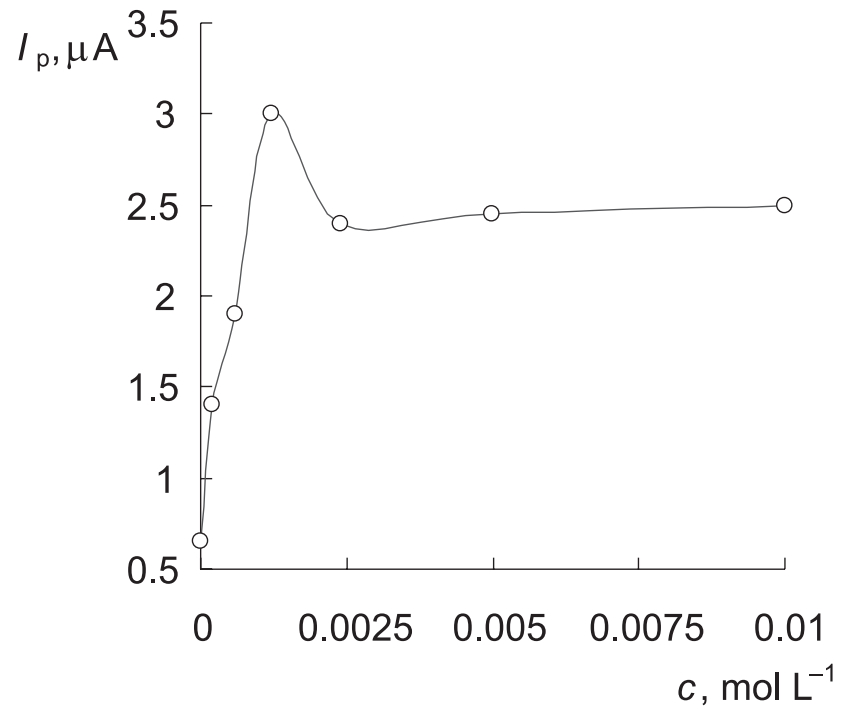

Fig. 1. The effect of the SDBS surfactant concentration on $\mathrm{KHSO}_{5}$ reduction peak at the carbositall electrode (the reference electrode $\mathrm{Ag}, \mathrm{AgCl} / \mathrm{KCl}(\mathrm{sat})) ; \mathrm{c}\left(\mathrm{KHSO}_{5}\right)=5.4 \times 10^{-5} \mathrm{~mol} \mathrm{~L}^{-1} ; E_{\mathrm{p}}=+0.3 \mathrm{~V}$.

is shifted toward more electronegative values with increasing of the background electrolyte $\mathrm{pH}$ from 0.80 to 7.17. The maximum peak $\left(I_{\mathrm{p}}\right)$ occurs at the $\mathrm{pH}$ of approximately 0.8 , and at the $\mathrm{pH}$ around 5 the analytical signal almost disappears. The effect of $\mathrm{pH}$ on the peak potential $\left(E_{\mathrm{p}}\right)$ shows the following: when the $\mathrm{pH}$ value increases in the interval from 0.8 to $2, E_{\mathrm{p}}$ remains almost constant, but $E_{\mathrm{p}}$ decreases sharply to a negative value with $\mathrm{pH}$ increasing over 2 . That is why the optimum $\mathrm{pH}$ for analysis is $\leq 2$ [3].

The effect of a surfactant

It has been experimentally proven that SDBS leads to increase of the current peak and the peak potential shifts to more electropositive side $(+0.25 \rightarrow+0.3 \mathrm{~V})$ (Fig. 1).

The current increases probably due to alleviation of desorption of reduction products from the electrode surface, and acceleration of the electron transfer in the course of electrochemical reactions is caused by the ability of SDBS to adsorb on the hydrophobic surface of the electrode and to form a surface film that changes the overpressure $[1,19,23]$.

The influence of the present SDBS was examined. The current peak increases with the concentration of the surfactant up to $1.2 \times 10^{-3} \mathrm{~mol} \mathrm{~L}^{-1}$ and then stays almost constant with the increase in the concentration of SDBS above $3.0 \times 10^{-3} \mathrm{~mol} \mathrm{~L}^{-1}$ (Fig. 1). That is why the optimum SDBS concentration for analysis is $\geq 3.0 \times 10^{-3} \mathrm{~mol} \mathrm{~L}^{-1}$.

It is known that Ecocid $\mathrm{S}$ disinfectant contains SDBS in the amount of $15 \%$ of the total content, i.e. in $0.5 \%$ of the working solution the concentration of SDBS is about $7.5 \times 10^{-4} \mathrm{~mol} \mathrm{~L}^{-1}$. So, it was decided to use the method of the calibration graph to quantify the concentration of $\mathrm{KHSO}_{5}$ in "Ecocid S" in the presence of SDBS excess $\left(4.0 \times 10^{-3} \mathrm{~mol} \mathrm{~L}^{-1}\right)$.

The procedure of obtaining results for the calibration graph

Working solutions were prepared by diluting 1.00 , $2.00,3.00,4.00$ and $5.00 \mathrm{~mL}$ of the stock solution with $10 \mathrm{~mL}$ of $1 \mathrm{~mol} \mathrm{~L}^{-1}$ background solution and $1 \mathrm{~mL}$ of 
Table 1

Analytical characteristics of the calibration graph of the $\mathrm{KHSO}_{5}$ voltammetric determination procedure in the presence of SDBS

\begin{tabular}{|l|c|}
\hline Parameters & Value \\
\hline Concentration ranges $\left(\mathrm{mol} \mathrm{L}^{-1}\right)$ & $(1.8-9.0) \times 10^{-5}$ \\
\hline Regression equation & $I_{\mathrm{b}}=(4.3 \pm 1.1) \times 10^{4} \mathrm{C}$ \\
\hline $\mathrm{a}$ & $4.3 \times 10^{4}$ \\
\hline $\mathrm{b}$ & 0.04 \\
\hline $\mathrm{S}_{\mathrm{a}}$ & $2.6 \times 10^{3}$ \\
\hline $\mathrm{S}_{\mathrm{b}}$ & 0.09 \\
\hline$\Delta a$ & $1.1 \times 10^{4}$ \\
\hline$\Delta b$ & 0.41 \\
\hline Correlation coefficient $(r)$ & 0.998 \\
\hline LOD $\left(\mathrm{mol} \mathrm{L}^{-1}\right)$ & $6.50 \times 10^{-6}$ \\
\hline LOQ $\left(\mathrm{mol} \mathrm{L}^{-1}\right)$ & $2.17 \times 10^{-5}$ \\
\hline
\end{tabular}

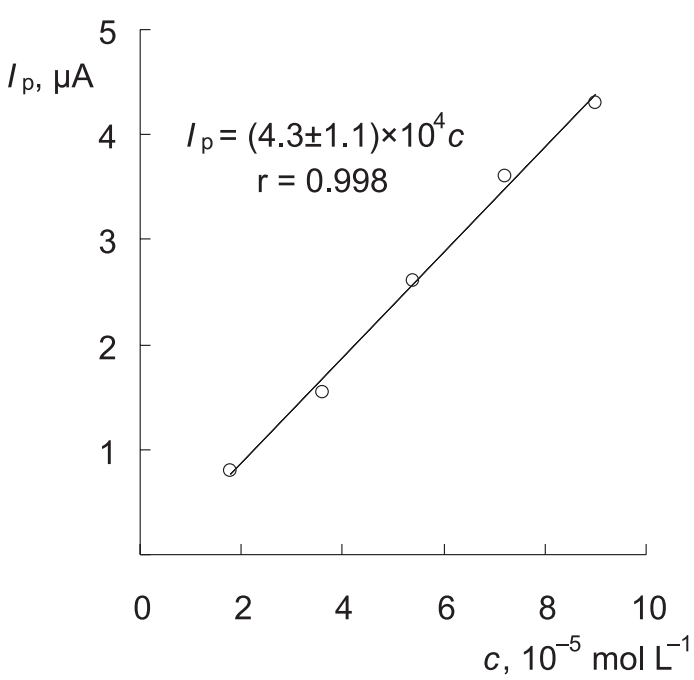

Fig. 2. The calibration graph of the reduction current peak of $\mathrm{KHSO}_{5}$ vs. concentration in the presence of SDBS $\left(c=4.0 \times 10^{-3} \mathrm{~mol} \mathrm{~L}^{-1}\right) ; E_{\mathrm{p}}=+0.3 \mathrm{~V}$.

Table 2

The results of voltammetric determination of potassium hydrogenperoxomonosulfate in "Ecocid S" $(n=5 ; \mathrm{P}=0.95 \%)$

\begin{tabular}{|c|c|c|c|c|c|}
\hline Taken, $\mathrm{mol} \mathrm{L}^{-1}$ & Found, $\mathrm{mol} \mathrm{L}^{-1}$ & Reproducibility $(\% \pm \mathrm{SD})$ & $\mathrm{RSD}, \%$ & $\varepsilon(\%)$ & $\delta^{*}(\%)$ \\
\hline $4.65 \times 10^{-5}$ & $(4.63 \pm 0.14) \times 10^{-5}$ & $99.57 \pm 2.49$ & 0.025 & 3.1 & -0.43 \\
\hline $6.20 \times 10^{-5}$ & $(6.21 \pm 0.13) \times 10^{-5}$ & $100.22 \pm 3.01$ & 0.023 & 3.0 & +0.16 \\
\hline $7.75 \times 10^{-5}$ & $(7.70 \pm 0.20) \times 10^{-5}$ & $99.64 \pm 2.32$ & 0.021 & 2.55 & -0.64 \\
\hline
\end{tabular}

* Relative to the average reference method of iodometric titration [15].

$0.2 \mathrm{~mol} \mathrm{~L}^{-1} \mathrm{SDBD}$ each in a $50 \mathrm{~mL}$ volumetric flask by double distilled water. $25 \mathrm{~mL}$ of the working solution of a pure substance was transferred to the cell. The voltammograms were recorded by scanning the potential toward the negative direction in the potential range from $+1.0 \mathrm{~V}$ to $-1.2 \mathrm{~V}$. All data were obtained at room temperature.

The graph was plotted in the following coordinates: the height of peaks $I_{\mathrm{p}}$ in $\mu \mathrm{A}$ at $0.3 \mathrm{~V}$ on the ordinate axis and the corresponding concentration of $\mathrm{KHSO}_{5} c$ in $\mathrm{mol} \mathrm{L}^{-1}$ on the abscissa axis (Fig. 2).

Analytical characteristics of the calibration graph of the $\mathrm{KHSO}_{5}$ voltammetric determination procedure are given in Tab. 1.

The procedure for quantitative determination of $\mathrm{KHSO}_{5}$ in "Ecocid $S$ "

The test solution was prepared by dissolving $0.5 \mathrm{~g}$ of the powder in a $100 \mathrm{~mL}$ volumetric flask by double distilled water to give the concentration of $7.75 \times 10^{-3} \mathrm{~mol} \mathrm{~L}^{-1}$. $10 \mathrm{~mL}$ of $7.75 \times 10^{-3} \mathrm{~mol} \mathrm{~L}^{-1} \mathrm{KHSO}_{5}$ was diluted in a $100 \mathrm{~mL}$ volumetric flask with double distilled water to obtain $7.75 \times 10^{-4} \mathrm{~mol} \mathrm{~L}^{-1}$ of $\mathrm{KHSO}_{5}$ solution.

Working solutions were prepared by diluting 3.00, 4.00 and $5.00 \mathrm{~mL}$ of the stock solution with $10 \mathrm{~mL}$ of $1 \mathrm{~mol} \mathrm{~L}^{-1}$ background solution and $1 \mathrm{~mL}$ of $0.2 \mathrm{~mol} \mathrm{~L}^{-1}$ SDBD each in a $50 \mathrm{~mL}$ volumetric flask by double distilled water. $25 \mathrm{~mL}$ of the working solution of a pure substance was transferred to the cell. The voltammo- grams were recorded by scanning the potential toward the negative direction in the potential range from $+1.0 \mathrm{~V}$ to $-1.2 \mathrm{~V}$.

The $\mathrm{KHSO}_{5}$ content $C_{\mathrm{x}}$, mol L-1 was calculated by:

$$
C_{\mathrm{x}}=\frac{I_{\mathrm{p}}-b}{a} \text {. }
$$

The high sensitivity of this method is accompanied by a very good reproducibility. The reproducibility was evaluated by 5 repeated electrochemical signal measurements of model solutions with the concentrations of $\mathrm{KHSO}_{5}$ of $3.6 \times 10^{-5}, 4.5 \times 10^{-5}$ and $5.4 \times 10^{-5} \mathrm{~mol} \mathrm{~L}^{-1}$. The precision of the method developed in terms of the relative standard deviation (RSD) was $0.025,0.023$ and $0.021(\delta=-0.64 \ldots+0.16 \%)$, respectively. The results obtained are summarized in Tab. 2.

\section{CONCLUSIONS}

Thus, a new voltammetric method of PMS determination in the presence of SDBS at the carbositall electrode using the method of the calibration graph has been developed and the possibility of its quantitative determination has been shown.

The linear dependence is observed in the PMS concentration range $(1.8-9.0) \times 10^{-5} \mathrm{~mol} \mathrm{~L}^{-1}$, the calibration curve equation is $I_{\mathrm{p}}=(4.3 \pm 1,1) \times 10^{4} \mathrm{c}(\mathrm{r}=0.998) ; \mathrm{RSD}=$ $0.025 \ldots 0.021$ and $\delta=-0.64 \ldots+0.16 \%(n=5 ; \mathrm{P}=0,95 \%)$, $\mathrm{LOD}=6.50 \times 10^{-6} \mathrm{~mol} \mathrm{~L}^{-1}, \mathrm{LOQ}=2.17 \times 10^{-5} \mathrm{~mol} \mathrm{~L}^{-1}$. 


\section{REFERENCES}

1. Bakun V.A., Fedulov D.M., Osipova E.A. et al. // Vestnik MITKhT. - 2009. - Vol. 4, №3. - P. 80-84.

2. Bengtong Ph., Thomrongsuwannakij T., Chansiripornchai N. // Thai J. Vet. Med. - 2013. - Vol. 43 (3). P. 405-409.

3. Blazheyevskiy M.Ye., Mozgova O.O. // J. Chem. Pharm. Res. - 2013. - Vol. 5(11). - P. 489-496.

4. Hernandez A., Martro E., Matas L. et al. // J. Hosp. Infect. - 2000. - Vol. 46. - P. 203-209.

5. Kreyngold S.U. // Dez. delo. - 2003. - Vol. 1. - P. 45-46.

6. Manjunatha J.G., Kumara Swamy B.E., Mamatha G.P. et al. // Int. J. Electrochem. Sci. - 2010. - Vol. 5. P. 1236-1245.

7. Marchetti V., Mancianti F., Cardini G. et al. // Vet. Res. Com. - 2006. - Vol. 30. - P. 255-261.

8. McCormick L., Maheshwari G. // Antiviral Res. - 2004. - Vol. 64. - P. 27-33.

9. Moslehifard E., Nasirpouri F., Gasemzadeh S. // J. Islamic Dent. Assoc. Iran (JIDA). - 2013. - Vol. 25 (2). P. 127-133.

10. Ozkan S.A., Uslu B., Enein H.Y. // Crit. Rev. Anal. Chem. - 2003. - Vol. 33. - P. 155-181.

11. Ossadnik S., Schwedt G. // Fresenius J. Anal. Chem. - 2001. - Vol. 371. - P. 420-424.

12. Roy P.R., Okajima T., Ohsaka T. // Bioelectrochem. - 2003. - Vol. 59. - P. 11.

13. Ruttinger H.-H., Radschuweit A. // J. Chrom. - 2000. - Vol. 868. - P. 127-134.

14. Suinjevic D., Blagojevic S., Vucelic D. et al. // Electroanalysis. - 1991. - Vol. 9 (1). - P. 861-864.

15. Tsvirova I.M., Panteleeva L.G., Fedorova L.S. et al. Instruktsiya 1 po primeneniju sredstva ECOCID ${ }^{\circledR}$, KRKA, Novo mesto (Slovenia) dlja tseley dezinfektsii i predsterilizatsionnoy ochistki. - M.: FGUN NII dezinfektologii Rospotrebnadzora Rossii, 2007. - 13 p.

16. Uslu B., Ozkan S.A. // Anal. Lett. - 2003. - Vol. 40. - P. 817-853.

17. Uslu B., Ozkan S.A. // Comb. Chem. High Through Screen. - 2007. - Vol. 10. - P. 495-513.

18. Wang H., Zhang Y., Gao Sh. et al. // CIESC J. - 2010. - Vol. 61. - P. 82-85.

19. Wang J. Electroanalytical Chemistry. 3rd ed., Wiley-VCH Pub., NewJerrey, 2006.

20. Westbroek Ph., Hakuzimana J., Gasana E. et al. // Sensors and Actuators. - 2007. - Vol. 124. - P. $317-322$.

21. Zhang J., Oloman C.W. // J. Appl. Electrochem. - 2005. - Vol. 35. - P. 945-953.

22. Ziyatdinova G.K., Ziganshina E.R., Budnikov H.C. // J. Anal. Chem. - 2012. - Vol. 67 (11). - P. $869-879$.

\section{КІЛЬКІСНЕ ВИЗНАЧЕННЯ ГІДРОГЕНПЕРОКСОМОНОСУЛЬФАТУ КАЛЮЮ У ДЕЗІНФЕКЦІЙНОМУ ЗАСОБІ «ЕКОЦИД С» МЕТОДОМ ВОЛЬТАМПЕРОМЕТРІЇ М.Є.Блажеєвський, О.О.Мозгова}

Ключові слова: калію гідрогенпероксомоносульфрат; вольтамперометрія; вуглеситаловий електрод; NаДБС; дезінфекційний засіб

Методом катодної вольтамперометрії з використанням як індикаторного вуглеситалового електрода вивчено електрохімічну поведінку калію гідрогенпероксомоносульфрату $\left(\mathrm{KHSO}_{5}\right)$ y присутності поверхнево-активної речовини натрію додецилбензенсульфонату (NaДБС) на фоні 0,2 моль/л розчину $\mathrm{KHSO}_{4}$ в інтервалі потенціалів $E=+1,0 \ldots-1,2$ B (відн. нас. XCE) $\left(E_{n}=+0,3\right.$ B). Було встановлено, що зі збільшенням рН середовища фонового електроліту від 0,80 до 7,17 висота піку відновлення $\mathrm{KHSO}_{5}$ зменшується, а потенціал піку відновлення зсувається у бік більш електронегативних значень, причому при рН біля 5 аналітичний сигнал практично зникає. Максимальний пік $\left(I_{n}\right)$ спостерігався при рН 0,8-2, а також за цих умов потенціал піку практично не змінювався. Експериментально встановлено, що аДБС, котрий входить до складу випробовуваного засобу, призводить до збільшення сили струму у максимумі піку та зсуває потенціал піку у більш електропозитивний бік $(+0,25 \rightarrow+0,3$ B). Вивчення впливу концентрації NaДБС на висоту піку відновлення $\mathrm{KHSO}_{5}$ показало, що при зростанні концентрації NаДБС до 1,2·10-3 моль/л висота піку стрімко зростає, а при досягненні 3,0·10-3 моль/л залишається практично незмінною. Лінійна залежність спостерігалася у діапазоні концентрацій $\mathrm{KHSO}_{5}(1,8-9,0) \cdot 10^{-5}$ моль/л, рівняння градуювального графріка: $I_{n}=(4,3 \pm 1,1) \cdot 10^{4} c(r=0,998)$. При визначенні $\mathrm{KHSO}_{5}$ у розчинах дезінфекційного засобу «Екоцид С» з концентраціями 4,65·10-5, 6,20 10-5 і 7,75.10-5 моль/л RSD дорівнювало 0,025, 0,023 та 0,021, відповідно ( $\delta=-0,64 \ldots+0,16 \%)$; $L O D=6,50 \cdot 10^{-6}$ моль/л, LOQ = 2,17.10-5 моль/л. 


\section{КОЛИЧЕСТВЕННОЕ ОПРЕДЕЛЕНИЕ ГИДРОГЕНПЕРОКСОМОНОСУЛЬФАТА КАЛИЯ В ДЕЗИНФЕКЦИОННОМ СРЕДСТВЕ «ЭКОЦИД С» МЕТОДОМ ВОЛЬТАМПЕРОМЕТРИИ Н.Е.Блажеевский, Е.А.Мозговая}

Ключевые слова: гидрогенпероксомоносульфат калия; вольтамперометрия; углеситаловый електрод; NаДБС; дезинфицирующее средство

Методом катодной вольтамперометрии с использованием как индикаторного углеситаллового электрода изучено электрохимическое поведение гидрогенпероксомоносульфата калия $\left(\mathrm{KHSO}_{5}\right)$ в присутствии поверхностно-активного вещества додецилбензенсульфоната натрия (NаДБС) на фоне 0,2 моль/л раствора $\mathrm{KHSO}_{4}$ в интервале потенциалов $E=+1,0 \ldots-1,2 \mathrm{~B}$ (отн. нас. ХCE) $\left(E_{n}=+0,3\right.$ В). Было установлено, что при увеличении рН среды фонового электролита от 0,80 до 7,17 высота пика восстановления $\mathrm{KHSO}_{5}$ уменьшается, а потенциал пика восстановления сдвигается в сторону более электроотрицательных значений, причем при рН около 5 аналитический сигнал практически исчезает. Максимальный пик (Iп) наблюдался при рН 0,8-2, а также в этих условиях потенциал пика практически не изменяется. Экспериментально установлено, что ㄱДБС, который входит в состав исследуемого средства, приводит к увеличению силы тока в максимуме пика и сдвигает потенциал пика в более электроположительную сторону $(+0,25 \rightarrow+0,3$ B). Изучение влияния концентрации $\mathrm{NaДБС} \mathrm{на} \mathrm{высоту} \mathrm{пика} \mathrm{восстановления} \mathrm{KHSO}_{5}$ показало, что при увеличении концентра-

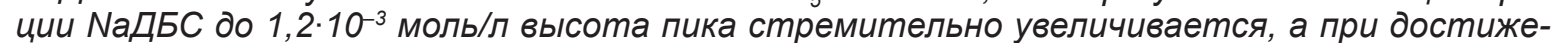
нии 3,0 10-3 моль/л остается практически неизменной. Линейная зависимость наблюдалась в диапазоне концентраций $\mathrm{KHSO}_{5}(1,8-9,0) \cdot 10^{-5}$ моль/л, уравнение градуировочного графрика: $I_{n}=(4,3 \pm 1,1) \cdot 10^{4} \mathrm{c}(r=0,998)$. При определении $\mathrm{KHSO}_{5}$ в растворах дезинфицирующего

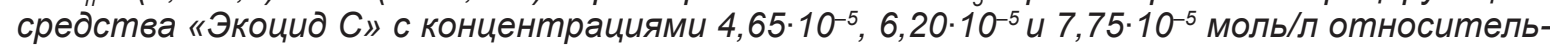
ное стандартное отклонение (RSD) составило 0,025, 0,023 и 0,021 соответственно ( $\delta=$ $-0,64 \ldots+0,16 \%) ; L O D=6,50 \cdot 10^{-6}$ моль/л, $L O Q=2,17 \cdot 10^{-5}$ моль/л. 